\title{
CHARACTER-BASED LEARNING AND SELF-DEVELOPMENT TO IMPROVE THE STUDENTS' CHARACTER EDUCATION
}

\author{
Samsinar ${ }^{1}$, Fitriani ${ }^{2}$ \\ 1,2Institut Agama Islam Negeri Bone \\ ${ }^{1,2} \mathrm{Jl}$. Hos Cokroaminoto Watampone \\ Email : samsinarakbar77@yahoo.com¹, fitri.angel91@gmail.com²
}

\begin{abstract}
:
This study aimed to describe character-based learning, to identify self-development forms, to find out the application of character education, and to find out whether there was a significant influence between character-based learning and self-development in improving the students' character education at Islamic Junior High School in Bone Regency. The method used was mixed-method. The sample of this research consisted of 50 students. The instruments used were questionnaire, observation guidelines, interview and document. The findings indicated that the implementation of character education was carried out through inculcating values, exemplary values, facilitation, academic activities, social, and religious activities. The application of selfdevelopment activities was done through routine, spontaneous, exemplary, programmed activities and conditioning. The character education was carried out through the application of class-based character education, school culture, and community-based character education activities. Therefore, there was a significant influence between the character-based learning process and self-development activities on improving the students' character.
\end{abstract}

\begin{abstract}
Abstrak:
Penelitian ini bertujuan untuk mendeskripsikan pembelajaran berbasis karakter, mengidentifikasi bentuk-bentuk pengembangan diri, mengetahui penerapan pendidikan karakter, dan mengetahui apakah ada pengaruh yang signifikan antara pembelajaran berbasis karakter dan pengembangan diri dalam meningkatkan pendidikan karakter siswa pada SMP Islam di Kabupaten Bone. Kombinasi metode penelitian kualitatif dan kuantitatif digunakan dalam penelitian ini. Sampel penelitian ini terdiri dari 50 siswa. Instrumen yang digunakan adalah kuesioner, pedoman observasi, wawancara dan dokumen. Hasil penelitian ini menunjukkan bahwa pelaksanaan pendidikan karakter dilakukan melalui penanaman nilai-nilai keteladanan, fasilitasi, dan kegiatan pengembangan akademik, sosial dan keagamaan pada SMP Islam di Kabupaten Bone. Penerapan kegiatan pengembangan diri melalui kegiatan rutin, spontan, keteladanan, kegiatan terprogram dan pengkondisian. Pendidikan karakter dilakukan melalui penerapan pendidikan karakter berbasis kelas, budaya sekolah, dan kegiatan pendidikan karakter berbasis masyarakat. Oleh karena itu, terdapat pengaruh yang signifikan antara proses pembelajaran berbasis karakter dan kegiatan pengembangan diri pada peningkatan karakter siswa.
\end{abstract}

Keywords:

Character Based Learning, Personal Development, Character Education

How to Cite: Samsinar, \& Fitriani. (2020). Character-Based Learning and Self-Development to Improve the Students' Character Education. Lentera Pendidikan : Jurnal Ilmu Tarbiyah dan Keguruan, 23(1), 108-126. https://doi.org/10.24252/lp.2020v23n1i10. 


\section{INTRODUCTION}

Good parents are parents who do more than just give love and fulfill the needs of their children, but parents must plan how they will shape the character of their children as proposed by Mullins (Aqib, 2015). In the schools, character education is a movement that inspires schools around the world to foster ethical, responsible, and caring young people by modeling and teaching good character through an emphasis on universal good values. It is the intentional, proactive effort by school, community, and states to teach the students' important core namely ethical values (Utami, 2012). The school environment is a good place to instill students' character. The school environment is conditioned so that the physical and socio-cultural environment of the school allows the students together with school residents to be accustomed to build daily activities in the school that reflect the manifestation of values or characters. Through this step, it will build a school culture that reflects the values of characters such as clean, disciplined, critical, courtesy, and tolerant. School culture includes ritual activities, expectations, social cultural relations, demographic aspects, curricular activities, extracurricular activities, decision making processes, policies, and social interactions among components in the school. Therefore, all activities in the school both learning and habituation activities can be integrated in the character education program (Supraptiningrum \& Agustini, 2015).

In the community, character values, life values, mutual respect, mutual cooperation, and honesty must be taught to bring character education to the community. Therefore, all parties must play an important role in improving character education. Enhancing and developing character education can be done by instilling basic ethical values or core ethical values as a basis for good character. The goal is the formation of good character.

Character education in a universal context emerges and develops initially based on the idea that schools are not only responsible for educating students to be merely intelligent, but also responsible for empowering students to have the personality, moral values, and character that guide them in daily life. To realize this, character education is not only in schools but also in the family and community. In the family environment, parents have an important role and become the first and foremost place in instilling character education. In general, there are five priority character values in childcare, namely teaching children to be diligent in worship, honest, respectful, harmonious, and learning achievement (Lestari, 2018: 167-171). In order for this value to be embedded in children, parents must use appropriate methods in instilling the character's values through dialogue, giving examples, giving advice, and asking without giving examples (Lestari, 2018: 173). Of the four methods, the last method does not support the success of the socialization process of values in children, because there is no exemplary element from parents and the child will ignore what is ordered. The previous three methods must be maximized so that the character values internalized in the child.

In addition to the family environment, the community environment must also make a positive contribution to the cultivation of character values in children. Community environment must provide full support by demonstrating the values of morality and example, and provide an environment or atmosphere that is conducive to the development of children's character. 
There are several criteria for the definition of character education namely promotes core ethical values as the basis of good character; parents and other community members are active participants in the character education initiative; character education entails an intentional, proactive and comprehensive approach that promotes core values in all phases of school life (i.e., cafeteria, transportation, playground, classroom, etc.), staff share responsibility for character education and attempt to model good character; this school fosters an overall caring community as well as in each classroom; this school provides opportunities for most students to practice moral action (Benninga, Berkowitz, Kuehn, \& Smith, 2003: 24). Good character indicators consist of understanding and caring for basic ethical values, and actions based on core ethical values. For this reason, character must be comprehensively defined which in its development touches on cognitive, affective, and behavioral aspects (Zubaedi, 2012).

Character education promotes the core value of hard work, responsibility, love and caring, respect, honesty, justice, humor, and self-control through teaching (Chao-Shun \& Ro-Yu, 2007). Character cover five areas: attitudes and behaviors in the relations with God, attitudes and behaviors in the relations with someone, and behaviors in the relations with family, attitudes and behaviors in the relations with society and nation, and attitudes and behaviors in the relations with surroundings (Sunarto \& Sagirani, 2014). Character education is not merely to teach what is right and what is wrong to the child, but more character education inculcate the good habit that students understand, able to feel, and want to do it (A. Kamaruddin, 2012). Character education can be done through the stages of knowing, acting and habit (Pranowo, 2013: 5). In addition, Ms \& Swadayani (2014) states that character education involves aspects of cognitive, feeling and action, without these three aspects, character education is not effective.

Character education can be seen with what was expressed by an educational expert Thomas Lickona from Cortland University in Kurniasih \& Sani (2017: 3) stated that there are ten signs to watch out, if these signs already exist in a nation then it will experience destruction. The signs are the increase of violence among adolescents, using bad language and words, strong group influences violence, the increase of self-destructive behavior such as drugs, alcohol, free sex, good and bad thing become blur, decrease of work ethic, lower respect for parents and teachers, low sense of individual and citizen responsibility, dishonesty, mutual suspicion, and hatred between people.

Nowadays, character education is very important and urgent because of the various events and situations facing the nation and state today. There are more growing and rampant values of hedonism, free sex, drug abuse, and violence that no longer need for faith and piety (Samani \& Hariyanto, 2017). Seeing the phenomenon, the parents who play a role in the informal education environment, course institution, equality education and other non-formal educational institution through co-curricular and extracurricular activities, the creation of institutional culture, formal education take place at elementary school, junior high school, senior high school, and tertiary institutions through learning, self-development activities, extracurricular activities, the creation of religious culture and habituation carried out in schools demand to implement character education. 
Implementation of character education in the formal education pathway can be done through the process of learning, education management and personal development activities. In the learning process, character education is integrated in learning in each subject. Learning materials related to norms or values in each lesson are developed, made explicit, and related to the context of everyday life. Thus, the learning of character values is not only on the cognitive aspect, but touches on internalization, and real practice in the daily lives of students in the community (At-Taubany \& Suseno, 2017).

In addition to the learning process, management of school education also contributes greatly to character education. The management of character education must be planned, carried out and controlled in educational activities in educational institutions adequately. Thus the management of school education is one of the effective media in character education in educational institutions. In addition, self-development activities can also shape the of students' character and aim to determine the students' talent interest (Suharso \& Nusantoro, 2013). This activity is an effort to shape students' personality traits through counseling activities related to personal problems and social life, learning activities, career development and other activities aimed at developing students' potential optimally, that is to become people who are able to organize themselves and respond to challenges both from himself/herself and from his/her environment in an adaptive and constructive manner, both within the family and community (At-Taubany \& Suseno, 2017).

Educational Value Standard Agency (BSNP) and the Curriculum Center for the Research and Development Agency of the Ministry of National Education stated that selfdevelopment is an activity that aims to provide opportunities for students to develop and express themselves according to the needs, talents, interests, each counselee according to conditions local school and environment. Thus, it can be understood that self-development activities are activities that are carried out outside of classroom learning activities that are facilitated by guidance and counseling teachers, other teachers or education personnel who strive to develop the students' potentials, interests, talents, and abilities according to their needs and the conditions or the school environment.

One of the self-development activities is extracurricular activities. Extracurricular is an educational activity outside of school hours that is shown to assist the students' development, according to their needs, potentials, talents, and interests through activities specifically organized by the students and educational staff who are capable and authorized in school (Yanti, Adawiah, \& Matnuh, 2016).

The students in extracurricular activities can develop their character. This activity is a curricular activity carried out by students outside the learning hours of intra-curricular activities and co-curricular activities, under the guidance and supervision of the education unit that aims to develop the potential, talents, interests, abilities, personality, collaboration, and independence of students optimally according to the mandate of the goal of national education, Presidential Regulation of Republic of Indonesia Number 87 in 2017 concerning to strengthen character education in Chapter II Article 7 paragraphs 3-4 which discusses the implementation of strengthening the character education. In addition, Government Regulation Number 19 in 2005 concerning to National Education Standards 
Article 79 paragraph 2 point b states that extracurricular activities are included in the annual work plan of the education unit, and their activities need to be evaluated every semester by the education unit (Law of Republic of Indonesia on the National Education System and Government Regulation 2013 of Republic of Indonesia concerning to National Education Standards and Obligations, 2014).

There were several research findings related to character education, one of them was entitled the implementation of character education in the 2013 curriculum (Study at Madrasah Aliyah Negeri Serang City). The results of this study stated that the implementation of character education in Madrasah Aliyah Negeri Serang City was well realized and the 2013 curriculum became a reference for stakeholders in facilitating the application of character education in schools. The character values that are embedded in the students themselves, both during learning activities and during school activities had become a character formed in students of Madrasah Aliyah Negeri Serang City. Supporting activities and several supporting factors ranging from leadership to all stakeholders in the school, as well as facilities and infrastructure that support the needs of students to apply life skills in accordance with their potential (Gunawan \& Rosa, 2020).

In addition, a research findings conducted at SMPN 9 in Yogyakarta indicated that the strategy of implementing character education at SMPN 9 in Yogyakarta can be done through the integration of values, and ethics in subjects, internalizing positive values instilled by all school members, habituation and training, setting examples and role models, creating a character atmosphere at school, and civilizing. The implementation of character education was carried out through integration between character formation with learning, school management and extracurricular activities (Dalimunthe, 2016). Furthermore, research on curriculum problems and character education learning indicated that there were many problems in the curriculum and learning of character education, namely the formulation of a character education curriculum that was still below the group's political interests and overlaps with the civic education curriculum, Pancasila education and religious education and character education. Meanwhile the problem of character education learning boiled down to methods, an educational environment that was not conducive, and the loss of example from parents (Julaeha, 2019).

Those studies indicated that the character education would work well in schools if all school members support the implementation of character education. Synergy was needed both in the school environment, family and community. Therefore, not only teachers and school residents could apply it, but parents must also be a good role model for their children, and the government, community leaders, religious leaders and other communities must play a role in instilling and applying character values in the students' daily life.

The implementation of character education based on the survey at Islamic Junior High School in Bone District that has been carried out required the involvement of the Tri Educational Center (school, family, and environment). Not only the school, but parents who are in the family as the main and first element in instilling children's character education. Parents must be good models for their children and parents must provide full support to the school so that the school can successfully implement character education. 
Schools must also take an important role in the application of character education. This application can be done through character-based school management starting from the application of character-based learning processes in the classroom, and personal development activities that include extracurricular activities and civilizing characterbased schools. If the implementation is done maximally, the school will produce students who have well character. In addition, the community must also take a role in developing children's character so that the success of character education can be achieved effectively and efficiently. The intervention of these three educational aspects will produce children's character. Thus, if you want the children or the students have good character, it is not enough just the efforts of parents and the community, but school must also manage their school well in order to produce students who have good character. For this reason, this research is important so that schools especially Islamic Junior High Schools in Bone Regency maximize the application of character education.

\section{RESEARCH METHOD}

This research was field research using mixed method or a combination of qualitative and quantitative research methods. This combination method was used together in a research activity in order to obtain objective, complete, valid and reliable data. This combination method used a concurrent triangulation strategy model or design. This design model was defined as a research method that combined qualitative and quantitative research methods together, both in data collection and analysis, then comparing the data obtained which data could be combined and distinguished (Sugiyono, 2011). The research model was carried out in one stage by using qualitative and quantitative methods in a balanced manner or qualitative methods higher than the quantitative method or vice versa. The population of this research was the teachers and the students that consisted of 246. The sample in this study was 35 teachers and 50 students whom selected by using purposive sampling technique. Purposive sampling technique was a sampling technique with certain considerations. The sample chosen was considered to know the most about what was expected so that it would be easier for the researchers to explore the object of this research.

The research instruments used were questionnaire, observation guidelines, interview guides and documents. Observation was used as supporting data to collect data by directly observing research objects, in this case observing the processes and procedures of character education during learning activities and self-development activities of the students at Islamic Junior High School in Bone Regency. Questionnaire was used as a tool to gain data which related to data about the character-based learning process, selfdevelopment activities, and character education at Islamic Junior High School in Bone Regency. The interview was used to reveal information directly from the research subjects, they are the teachers and the students related to the character-based learning process, self-development activities, and character education at Islamic Junior High School in Bone Regency. In addition, researchers also did interview to the school principals to support information about character education implemented at Islamic Junior High School in Bone 
Regency. Documentation technique was used to obtain data about the learning tools used by teachers in the learning process including syllabus, lesson plan, teaching material and learning module, and self-development activity that were applied to support the character education at Islamic Junior High School in Bone Regency. Document analysis was done by recording the documents that had been and had not been owned by the teachers, analyzing the learning plan and its components both the learning objectives, indicators, methods that related to the character education approach, media and character-based learning evaluation.

Data were analyzed qualitatively and quantitatively. Qualitative data were analyzed through data reduction, data presentation and drawing conclusions. While quantitative data were analyzed through editing and scoring. Data analyses used of this research were inductive qualitative data analysis, quantitative descriptive data analysis, inferential analysis, hypothesis testing, and partial determination coefficient.

\section{RESULT AND DISCUSSION}

This study discussed character-based learning process, self-development activities, the application of character education, and the influence between character-based learning process and self-development activities on improving character education of the students at Islamic Junior High School in Bone Regency. Related to the character-based learning process, the teachers of Islamic Junior High School in Bone Regency had implemented it well according to the results of the questionnaire, observations, and the results of interview from the teachers, school principal, and students that stated in general the teacher had implemented character-based learning process. The questionnaire was given to 50 students and the following cumulative questionnaire results were obtained:

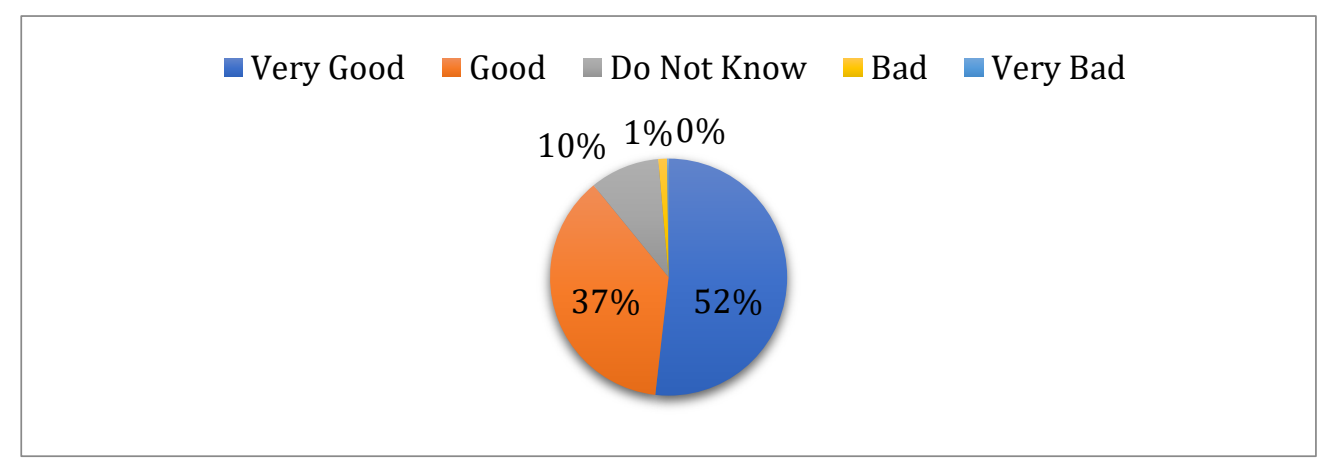

Picture 1. Character-Based Learning Process

To support the results of the questionnaire, the researchers conducted observation and interview activities so that the results of the study were obtained more valid and reliable. Observation activities carried out by observing class IX students consisting of three classes or 67 students then the researchers interviewed several of them by asking a number of questions relating to the character-based learning process activities implemented in the school. There were 10 teachers and 6 students selected because they knew more about what was studied. 
In addition, the results of observation and interview conducted by researchers at Islamic Junior High School in Bone Regency relating to the character-based learning processes through the inculcation of values by: (a) Treating Students Fairly. Based on interview from one of the teachers at Islamic Junior High School in Bone Regency, he said that there was no special treatment for the students who had high academic ability with the students who had below average academic ability. All of them were treated fairly without exception both in inside and outside learning class. However, there was special guidance given to students who need it such as a student who wanted to participate in a competition, a student who did not attend the class because of illness, and so on. (b) Respect The Others' Opinions. The observation result showed that in general the teacher in the learning process provided an opportunity for all students to express their ideas and opinions about what they had learned and always respected the students' opinions. (c) Always Providing Inspiration, Motivation, Emotional Touch and Reinforcement to The Students In Real Life. The results of the interview from one of the teachers at Islamic Junior High School in Bone Regency said that as teachers, they have to show the best for students. They would follow what the teachers did. If in the teachers' daily life, they did not do what they taught, then the students would no longer trust them and the teachers could not be the role model for them. In addition, they also always inspired the students, provided emotional touch and positive reinforcement so that the students were motivated to do good things. (d) Making Rules or Contracts in The Learning Process, Appreciating or Reward and Punish Students in The Learning Process. The observation showed that in general the teachers gave rewards to the students when successful in learning. Reward was given in the form of prizes such as photo frames that were displayed at school and given information about academic achievements obtained. In addition, the teachers also provided verbal and non-verbal reinforcement. Verbal positive reinforcement such as your idea was good, your opinion was correct, and positive reinforcement non-verbally by giving a thumbs up, patting the shoulder, and rubbing the head. (e) Creating social and emotional experiences about the moral values, assessing the students' attitudes related to certain values that were inculcated to the students such as religious values (ukhwah values, kinship and helping each other) that need to be internalized in students.

Character-based learning process activities through exemplary values had also been carried out by Islamic Junior High School teachers in Bone Regency such as follow: (a) Giving good examples to the students. (b) Starting and ending each of teaching and learning process by praying; interview results from Nuraeni, one of the principals of Islamic Junior High Schools in Bone Regency said that doing pray was not at the starting and ending the teaching and learning activities, but also every beginning of learning activities the students must read verses of the Qur'an or Hadith and that applied to all subjects without exception. In addition, every material taught was related to the verses of the Qur'an and Hadith, and the teacher conveyed the contents of the verse or Hadith. (c) Giving an example through good habits and discipline; Based on the researchers' observation, the teachers of Islamic Junior High School in Bone Regency had provided internal examples through good habits and taught about discipline. Good habits were 
usually done by the teacher such as honest in everything, consistent with what was done, responsible, and so on. The teachers also taught about discipline such as coming on time, being assertive, consistent with the rules that have been made for the students. (d) Providing an internal example through giving or telling stories about religious experiences. (e) Providing an exemplary through figures' stories that should not be emulated then show them the films' characters.

The previously explanation indicated that the teachers dad implemented characterbased learning through teaching and learning activities. Thus, it could be understood that the exemplary values both internal and external teachers of Islamic Junior High School in Bone Regency had been applied in the learning process to improve the students' character.

Another character-based learning process activity was facilitation. In terms of facilitation, the teachers of Islamic Junior High School in Bone Regency were being good listener for students, giving them opportunity to express their opinions, asking questions, recalling things that need to be listened to, and clarifying things that were still doubtful, facilitating students to accept a value and practice it in a way that be consistent or take moral action, facilitating them to think about values learned, finding their own insights, telling them to learn from other students who have received good score, and motivating the students by connecting values problems of his life, beliefs and feelings.

The last activity of the character-based learning process was the teachers developed the students' academic and social skills at Islamic Junior High School in Bone Regency. Based on the interview from Nuraeni, she said that learning activities did not only focus on academic and social development, but also fostering and developing students' religious skills including speech or sermons, prayer leaders, reading and memorizing the Qur'an according to the recitation. The interview was also supported by the researchers' observation for 1 month and religiosity assessment documents from Yeni Ana Puspita Sari as a counseling guidance teacher at one of the Islamic Junior High Schools in Bone Regency. The assessment of the students' religiosity consisted of becoming a prayer leader, performing congregational prayers, performing rawatib circumcision prayers, duha prayer, lail prayers, almsgiving, keeping ablution, tadarrus, fasting, tahyatul mosque prayer, and memorizing prayer readings. In developing academic and social skill, teacher had developed critical and creative thinking skill, improved problem solving skill and found conflict resolution, developed clear and effective communication skill, developed listening skill, developed skill for assertive action that was able to express opinions in ways that did not hurt the others' feelings.

In addition to the character-based learning process, self-development activities could also made the students' character. Based on the researchers' findings from the results of the questionnaire, observation, and interview, Islamic Junior High School in Bone Regency had implemented several activities related to students' self-development that could develop the students' character. The cumulative result of the self-development activities questionnaire at Islamic Junior High School in Bone Regency was presented the following picture: 


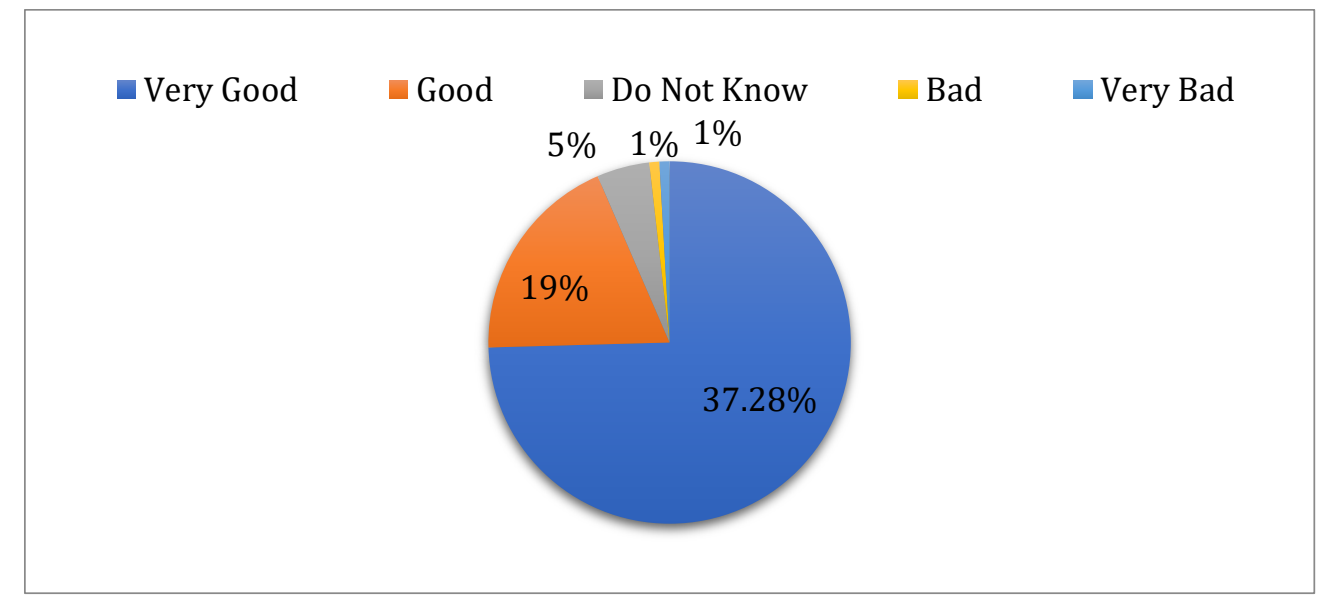

Picture 2. Personal Development Activities

Personal development activities were carried out through routine activities, spontaneous activities, examples, programmed activities, and facilitation. Routine activities such as school ceremonies, sports, worship activities in congregation such as congregational prayer, Monday and Thursday fasting or other sunnah fasting, maintaining hygiene and health.

Spontaneous activities undertaken by the students such as greeting, smiling, politeness, greeting others, picking up trash to the garbage, culturing the queue culture, especially when eating, entering the toilet, receiving report cards, etc. Besides that, the students were also able to overcome various problems and provide solutions for different opinions. This spontaneous activity was carried out without being limited by time, space and place. This activity provided spontaneous education for the students related to the development of school culture which was carried out in self-development activities.

Furthermore, other self-development activities were the teachers being good role model so that the students imitated and emulated their teachers, they provided positive reinforcement if the students succeed and did good things, but if they did bad things the teachers gave negative reinforcement or punishment such as additional worship, tadarrus, and giving alms.

The teachers or schools also created various self-development activities or programs such as guidance and counseling services to the students in the field of personal life development, social life development, learning activities, and career planning. Other activities were extracurricular activities both mandatory (Scouting and Youth Red Cross) and electives such as academic and non-academic extracurricular activities. Academic extracurricular activities such as Natural Sciences, Social Sciences, Biology, Physics, Mathematics, Geography and other general subjects in science. Based on the researchers' observation, the academic extracurricular activities were conducted once a week on Saturday for 5 hours. For non-academic extracurricular activities such as sports and Islamic Education performances should be selected according to the students' talents, interests and abilities. 
Mandatory extracurricular activities that must be followed by the students were religious activities. The interview from Bustam as a tahfidz teacher in an Islamic Junior High School in Bone Regency stated that there were some extracurricular activities that must be followed by the students namely tahfidz which was conducted in the afternoon until evening, technology skill such as electricity and multimedia, learning Arabic language, mukhaddarah and tarbiyah lectures or intensive religious guidance by providing the basics of religion, improving the reading of Qur'an, recitation, memorization of Qur'an and Hadith, giving material from murrobi and problem solving (problems that are faced by the students and how to solve it), and infaq (habituation to charity) which was done for social activities.

Self-development activities were also carried out by conditioning that was preparing various worship facilities and equipment to maintain cleanliness as well as facilities to motivate the students through talk boards made by the students or prepared by the school.

There were several steps taken by Islamic Junior High School in Bone Regency in implementing character education for students, namely class-based character education, school culture-based character education, and community-based character education. Character values had also been well implemented by the Islamic Junior High School in Bone Regency. The character values were:

Table 1. Application Character Values at Islamic Junior High School in Bone Regency

\begin{tabular}{|c|c|}
\hline Attitude & Indicator \\
\hline Discipline & $\begin{array}{l}\text { Obey the rules of school and boarding. } \\
\text { Obey the boarding schedule. } \\
\text { Obey the school schedule. } \\
\text { Obedient to work on lesson assignments. } \\
\text { Obedient to do the task of intimacy. }\end{array}$ \\
\hline Confidence & $\begin{array}{l}\text { Believe in your abilities. } \\
\text { Able to interact with others. } \\
\text { Confidence to speak, think and accept criticism. } \\
\text { Confidence to take a stand and not be afraid of being wrong. } \\
\text { Confidence to appear in public. }\end{array}$ \\
\hline Honest & $\begin{array}{l}\text { Do not cheat during exams and do school work. } \\
\text { Not doing plagiarism (plagiarizing other's work without } \\
\text { permission). } \\
\text { Not borrowing or taking other's property without } \\
\text { permission from the owner. } \\
\text { Dare to admit mistakes. } \\
\text { Conveying things as they are. }\end{array}$ \\
\hline Independent & $\begin{array}{l}\text { Wash the clothes yourself. } \\
\text { Wash own dishes independently. } \\
\text { Responsible for personal belongings. } \\
\text { Make the bed. } \\
\text { Keep items (books, clothes, etc.) in their place. }\end{array}$ \\
\hline
\end{tabular}




\begin{tabular}{|c|c|}
\hline $\begin{array}{l}\text { Be Devoted and } \\
\text { Respectful to } \\
\text { Parents and } \\
\text { Teachers }\end{array}$ & $\begin{array}{l}\text { Pray for parents and teachers. } \\
\text { Does not raise the voice when talking. } \\
\text { Do not say rude. } \\
\text { Pay attention and listen when getting advice from parents } \\
\text { and teachers. } \\
\text { Carry out the commands of parents and teachers } \\
\text { Familiarize tabe' culture (politeness). }\end{array}$ \\
\hline Tolerant & $\begin{array}{l}\text { Respect the others' opinions. } \\
\text { Respect differences (religion, ethnicity, race and social } \\
\text { status). } \\
\text { Do not do bullying. }\end{array}$ \\
\hline $\begin{array}{l}\text { Five S (Salam, } \\
\text { Smiles, } \\
\text { Greetings, } \\
\text { Politeness, } \\
\text { Manners) and } \\
\text { Five R (concise, } \\
\text { neat, clean, } \\
\text { caring and } \\
\text { diligent) }\end{array}$ & $\begin{array}{l}\text { Accustomed to greetings, smiles, etc. } \\
\text { Avoid dirty and rude words. } \\
\text { Speaking manners. } \\
\text { Respect for the older and love the younger. } \\
\text { See trash, take to garbage. } \\
\text { Take care of school, dormitory and home facilities. } \\
\text { Actively involved in cleaning the school, dormitory and } \\
\text { home environment. }\end{array}$ \\
\hline Eating manners & $\begin{array}{l}\text { Washing hands before and after eating. } \\
\text { Reciting Basmalah, pray before and after eating. } \\
\text { Eat and drink with your right hand. } \\
\text { No waste. } \\
\text { Maintain cleanliness. }\end{array}$ \\
\hline
\end{tabular}

Source: Document for Islamic Junior High Schools in Bone Regency

Application of character education in Islamic Junior High School in Bone Regency had been optimally carried out as the cumulative results from the questionnaire that had been administered to the students in Islamic Junior High School in Bone Regency. The results of the questionnaire were supported by observation and interview that the teachers and the students had implementing class-based character education. They became good relations in the classroom, interact multi-ways, teach character values in the learning process, work together in managing class, and create a pleasant learning atmosphere.

To strengthen the questionnaire, the results of an interview from Syahrir, one of the Islamic Junior High School teachers in Bone Regency, stated that the pattern of interaction carried out by the teachers in classroom-based character education was a pattern of interaction that was not only one-way, two-way but multi-directional. This intense interaction was carried out by always reminding the good things that must be done by the students and always istiqamah. Therefore, the teachers always provided escort character education programs both in the learning process and outside the learning process. The teachers and the students also work together in managing the class. Muh. Rifki Ar-Rahman, 
one of the Islamic Junior High School students, said that the teacher involved the students in managing the class and always prioritized cooperation in the learning process, especially in arranging and organizing the class well, starting with seating arrangements, accessories or completeness in class, extension of students' work in the form of class displays, and maintaining class cleanliness, etc.

Teachers and students of Islamic Junior High School in Bone Regency made agreement in the class as a step in the character-based learning process. An interview was done with Muh. Nurcholis, one of the teachers at Islamic Junior High School in Bone Regency, stated agreement in the class is always done through mutual agreement between the teachers and students in determining a number of things or finding solutions together to the problems faced in the classroom after a discussion between them. In this way, the teachers introduced behavioral responsibility through the involvement of students in decision making and problem solving.

Teachers and students have also created a pleasant learning atmosphere. Thus, Islamic Junior High School teacher in Bone Regency had been running the process of character-based learning in the classroom optimally so that this implementation made the students had good character.

Islamic Junior High School teacher in Bone Regency also built a school culture that was able to shape the students' character with the help of school social institutions so that certain values were formed and internalized within students. Therefore, there were several steps taken by Islamic Junior High School teacher in Bone Regency in shaping the students' character through school culture, they were: (a) Making strict and consistent rules on every despicable behavior carried out by the students; based on the interview from one of the students named Muhammad Safiq Hilmi stated that their school had made strict rules against violations or despicable acts committed by students. If a student broke the rules, he/she would be punished and might be excluded from the school despite he/she was having good academic performance and having been proud of the school's name for participating in the Olympics at the national level. This statement was also supported by Nuraeni, one of the principal of Islamic Junior High Schools in Bone Regency, she said that the school prioritized character over academics, as evidenced by the students who were champions of the National Science Olympiad who wanted to continue to high school level were not accepted because they broke character education which has been applied well to the students, and vice versa. There were students who had academic scores rather low and did not fulfill KKM (Minimum Completeness Criteria), but their character was good; always disciplined, obeying rules, honest and having good character, so that the school continue to keep them because character was more important than achievement. Achievement during education is quasi-character, and character was a complete achievement. (b) Giving moral messages; in general, the teachers of Islamic Junior High School in Bone Regency always provided moral messages for students as a step to strengthen the religious-based school culture. As a result of the researchers' observation, the teachers always gave moral messages wherever and whenever as motivation for the students to always do good things. (c) Maintaining school cleanliness; based on the interview with a teacher at Islamic Junior 
High School in Bone Regency named Agussalim, he stated that the creation of the religiousbased school culture was also carried out in dormitory by always maintaining cleanliness by obeying the 5-R rules namely neat, clean, diligent, caring and concise. $5-\mathrm{R}$ was always instilled to the students to be internalized themselves so that the implementation of character values could be achieved both at school and in the dormitory and also within the family and community. (d) Accustoming the students to think positively, be able to control thoughts, love each other, easy to get along with, forgiveness, not selfish and maintain health. (e) Always say thoyibah (good words or sentences) in their daily lives; based on the observation during the learning process, in the dormitory and at home, the students always said thoyibah such as Astagfirullah, Alhamdulillah, Subhanallah, Masha Allah and Allahu Akbar.

Based on the explanation about the findings related to shape the students' character, it described that the students always bring Islamic value to students' activities. Thus, all the students of Islamic Junior High School in Bone Regency had optimally cultivated school culture so that the students are of good character by applying the school religious culture.

The last step taken by Islamic Junior High School in Bone Regency in implementing character education was to shape the students' character with the help of school social institutions so that certain values are formed and internalized within the students. Therefore, there were several steps taken by the Islamic Junior High School in Bone Regency in shaping the students' character through community-based character education as follow: (a) Socializing to parents; the community and the government have moral responsibility in integrating the formation of children's characters in the context of daily life. (b) Involving parents in improving and developing the students' character; controlling students through activity sheets or book control in improving their character; based on the interview with one of the students named Fauzan Akbar, he stated that to control character education while in the dormitory, at school, and at home, the students' were given a sheet or control book that contained various religious activities conducted by the students called Amaliah Learners' control. This book or sheet contained monthly activities in congregational prayers, rawatib qabliyah sunnah prayers, rawatib ba'diyah, lail prayers, duha prayer, sunnah fasting, morning dhikr, evening prayer, recitations, shadaqah, dakwah, 5-R, and helping parents or doing home chores. These books or sheets were taken home by the students on holidays then it was controlled and signed by the students' parents when they were at home. Therefore, school involved the students' parents in fostering their children so that children had good character. (c) Involving the community in improving and developing the students' character; based on the interview with a student named Sitti Shofiyyah Isra Amri, she stated that the school involved the students' parents and the community in various religious activities, for example the school conducted joint qurban activities every year which are coordinated by the school with the help of parents and the community. Another activity was parents-day. This program was also carried out every semester through a competition between parents and children in the form of games to test the cohesiveness between the students and their parent. This activity was usually carried out at the time of receiving report cards. In addition, there 
were also food creation contests that were determined by the school's theme such as Bugis style food and other themes. Thus, the school had involved parents and the community in improving the students' character. (d) The Government gave appreciation to schools in improving the character of the nation; the community-based character education had been implemented well by Islamic Junior High School in Bone Regency, in order to produce students with character.

Some of the results of interviews and observations that have been carried out at Islamic Junior High Schools in Bone Regency supported the results of the questionnaire about character education. The results of the questionnaire in the picture 3 showed that Islamic junior high schools in Bone Regency had tried hard and optimized so that all parties involved in implementing character education were not only the school, but also need support from parents, the community, and the government.

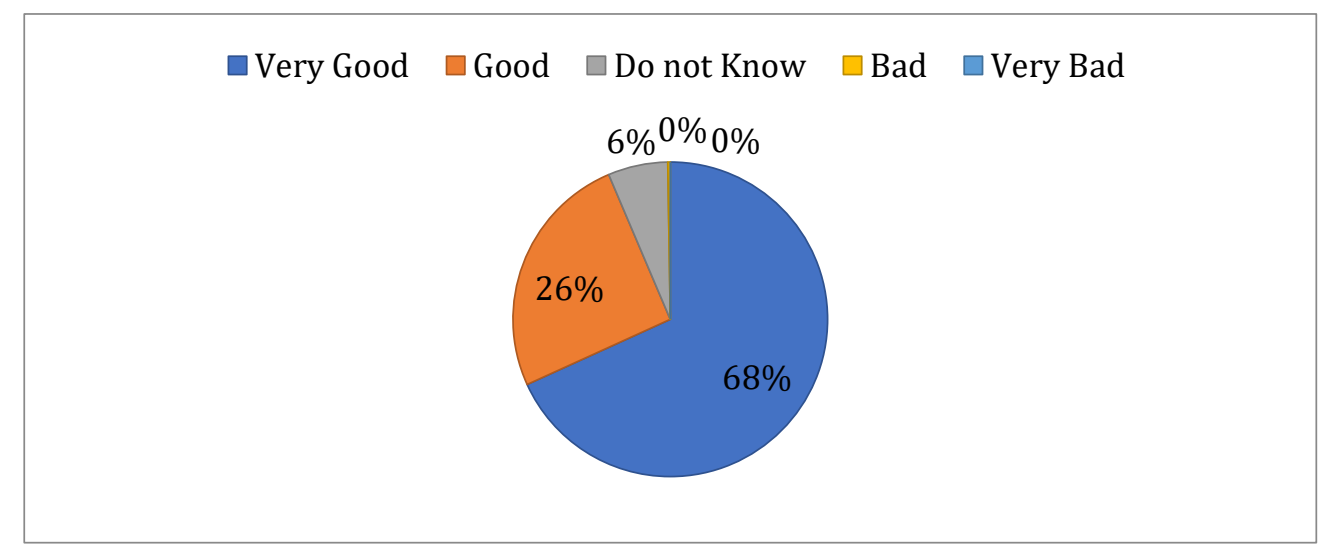

Picture 3. Character Education

Based on the research findings and analysis of this research, there was a significant influence between the learning process and self-development activities on improving the students' character education at Islamic Junior High School in Bone Regency. Other data analyses found were presented as follows:

Descriptive Statistics. The respondents were 50 people. The average increase of the students' character education at Islamic Junior High School in Bone Regency was 78.02 with 7.058 of standard deviation. With this standard deviation, if it was associated with the increase of the students' character by 78.02, then the increase in character would range between $78.02 \pm 7.058$. Average of character-based learning process was 87.88 with 7.761 of standard deviation and average of self-development activities was 95.98 with 7.673 of standard deviation. The answers given by the respondents for these two independent variables were very good.

Correlations, the result of calculating the correlation between the variable characterbased learning process (X1) with the increase of character education (Y) obtained was 0.693 . This score indicated that the contribution made by this variable to the variable (Y) was $\mathrm{KP}=(\mathrm{r})^{2} \times 100 \%=(0.693)^{2} \times 100 \%=48.02 \%$. Thus, based on a simple interpretation of the $r$ product moment $\left(r_{x} y\right)$ correlation index number. Therefore, the score of $r=0.693$, 
it could be said that between the character-based learning process variables to the character education variable had moderate correlation because it was in the position of 0.40-0.70. The result of the correlation between the variables of self-development activities (X2) with the increase in character education obtained score of $r=0.744$. This score indicated that the relationship between the two was strong positive. The point was that there was a direct relationship between X2 and Y. If the score of self-development activities (X2) improved, there would be a significant increase in the students' character education significantly. Contributions made by this variable to the variable ( $\mathrm{Y}$ ) were: $\mathrm{KP}=$ $(\mathrm{r})^{2} \times 100 \%=(0.744)^{2} \times 100 \%=55.35 \%$.

Based on the coefficients (a), it showed that the multiple regression equation model to predict the improvement of character education that was influenced by the characterbased learning process and self-development activities were: $Y=8.302+0.278 \mathrm{X}_{1}+0.472$ $\mathrm{X}_{2}$. $\mathrm{Y}$ was an increase in character education, $\mathrm{X}_{1}$ was a character-based learning process, and $X_{2}$ was a self-development activity. Based on the equation, it could be analyzed several things including: Increased character education, if without the character-based learning process and self-development activities $\left(X_{1}\right.$ and $\left.X_{2}=0\right)$, then the increase in character education was only $8.302=8$. Whereas, each respondent's answer increased by 1 point for answers to the character-based learning process and activities self-development $\left(X_{1}=50\right.$ and $X_{2}=50$ ), it was predicted that there would be an increase in character education and would rise to: $\mathrm{Y}=8.302+0.278 \mathrm{X}_{1}+0.472 \mathrm{X}_{2}$

$$
\begin{aligned}
& \mathrm{Y}=8.302+0.278(50)+0.472(50) \\
& \mathrm{Y}=45.8
\end{aligned}
$$

The multiple regression coefficients of 0.278 and 0.472 indicated that the magnitude of the increase in character education increased each addition of respondents' answer to the variable character-based learning process and self-development activities. The multiple regression equation $\mathrm{Y}=8.302+0.278 \mathrm{X}_{1}+0.472 \mathrm{X}_{2}$ which was used as a basis for predicting the improvement of character education that was influenced by the characterbased learning process and self-development activities, would be tested whether it was valid to use.

To test the validity of the multiple regression equation, two methods were used, namely a hypothesis based on the F-test (simultaneously) and t-test (partial) and a hypothesis based on a probability technique as follow:

Hypothesis based on the F test (simultaneously); the hypothesis based on the F-test was only used to find out whether the two independent variables together (simultaneously) affected one independent variable. The steps were:

(1) Make a hypothesis in sentence form

$\mathrm{H}_{0}$ : There was no significant simultaneous effect between the character-based learning process and self-development activities on improving character education.

$\mathrm{H}_{\mathrm{a}}$ : There was a significant simultaneous effect between the character-based learning process and self-development activities on improving character education. 
(2) Make a hypothesis in the form of a statistical model

$$
\begin{aligned}
& \text { Ho: } \beta=0 \\
& \text { Ha: } \beta \neq 0
\end{aligned}
$$

Testing rules:

If F_count $\leq \mathrm{F}_{-}$tabel, then $\mathrm{H}_{-} \mathrm{O}$ was accepted

If $F_{-}$count $>$F_table then $\mathrm{H}_{-} \mathrm{o}$ was rejected

Compares between F_calculate and F_tabel:

Based on the summary model table, the value of F-test $=34.299$ was obtained.

The value of F_table can be searched using table F by means of F-tabel $=F-((1-\alpha)(d k$ numerator $=\mathrm{m})$, $(\mathrm{dk}$ denominator $=\mathrm{n}-\mathrm{m}-1)$ )

Where:

$\mathrm{m}=2, \mathrm{n}=50$, and $\mathrm{a}=0.05$

Fable $=F_{-}((1-0.05)(2),(47))=4.7$

It turns out that F-test $=34.299>\mathrm{F}$-table $=4.7$ then Ho is rejected

Therefore, there was a significant simultaneous effect between the character-based learning process and self-development activities on improving character education.

\section{CONCLUSION}

The application of character-based learning process in Islamic Junior High School in Bone Regency was done by inculcating values, exemplary values, facilitation, and academic, social and religious development activities. Application of self-development activities in Islamic Junior High School in Bone Regency was done through routine activities, spontaneous, exemplary, programmed activities and conditioning. Improving the character education in Islamic Junior High School in Bone Regency was carried out through the application of class-based character education, school culture, and community-based character education activities. There was a significant influence between the character-based learning process and self-development activities on improving the students' character at Islamic Junior High School in Bone Regency. The average increase in the students' character education at Islamic Junior High School in Bone Regency was 78.02 with 7.058 of standard deviation. This standard deviation, if it was associated with the increase in the students' character by 78.02, then the increase in character would range between $78.02 \pm 7.058$. The average of character-based learning process was 87.88 with 7.761 of standard deviation and the average of self-development activities was 95.98 and 7.673 of standard deviation.

\section{REFERENCES}

Aqib, Z. (2015). Pendidikan Karakter di Sekolah: Membangun Karakter dan Kepribadian Anak (I). Bandung: Yrama Widya.

At-Taubany, T. I. B., \& Suseno, H. (2017). Desain Pengembangan Kurikulum 2013 di Madrasah (I). Jakarta: Kencana Prenada Media Group. 
Benninga, J., Berkowitz, M., Kuehn, P., \& Smith, K. (2003). The Relationship of Character Education Implementation and Academic Achievement in Elementary Schools. Journal of Character Education, 1(1), 19-32. file:///C:/Users/PC/Downloads/Documents/Character_Education.pdf.

Chao-Shun, C., \& Ro-Yu, L. (2007). Character Education and Character-trait Development: An Enrichment for College Students. Paper Presented at Koa Yuan University, Koashiung Country, 1-16.

Dalimunthe, R. A. A. (2016). Strategi Dan Implementasi Pelaksanaan Pendidikan Karakter Di Smp N 9 Yogyakarta. Jurnal Pendidikan Karakter, 1, 102-111. https://doi.org/10.21831/jpk.v0i1.8616.

Gunawan, A., \& Rosa, N. P. (2020). Implementasi Pendidikan Karakter (Studi di Madrasah Aliyah Negeri Kota Serang). Risalah: Jurnal Pendidikan Dan Studi Islam, 6(1), 6679. https://doi.org/10.31943/jurnal_risalah.v6i1,\%20March.126.

Julaeha, S. (2019). Problematika Kurikulum dan Pembelajaran Pendidikan Karakter. Jurnal Penelitian Pendidikan Islam, 7(2), 157. https://doi.org/10.36667/jppi.v7i2.367.

Kamaruddin, S. A. (2012). Character Education and Students Social Behavior. Journal of Education and Learning (EduLearn), 6(4), 223. https://doi.org/10.11591/edulearn.v6i4.166.

Kurniasih, I., \& Sani, B. (2017). Pendidikan Karakter: Internalisasi dan Metode Pembelajaran di Sekolah. Surabaya: Kata Pena.

Lestari, S. (2018). Psikologi Keluarga: Penanaman Nilai dan Penanganan Konflik dalam Keluarga (IV). Jakarta: Kencana Prenada Media Group.

Ms, B., \& Swadayani, B. (2014). Implementasi Program Pendidikan Karakter di SMP. Jurnal Pendidikan Karakter, 3, 235-244. https://doi.org/10.21831/jpk.v0i3.5627.

Pranowo, D. J. (2013). Implementation of character Education of Caring and Collaboration Through the Role Play Technique. Pendidikan Karakter, 3(1), 218-230. https://doi.org/10.21831/jpk.v2i2.1442.

Samani, M. \& Hariyanto. 2011. Konsep dan Model Pendidikan Karakter. Bandung: PT Remaja Rosdakarya.

Sugiyono. (2011). Metode Penelitian Kualitatif, Kuantitatif dan Kombinasi (Mixed Methods). Bandung: Alfabeta.

Suharso, B. R. A., \& Nusantoro, E. (2013). Studi Pengembangan Diri (Bakat Minat) pada Siswa Komunitas Sastra di Sekolah Alternatif Qoryah Thoyyibah Salatiga. Indonesian Journal of Guidance and Counseling: Theory and Application, 2(3), 7580. https://doi.org/10.15294/IJGC.V2I3.3191.

Sunarto, M. J. D., \& Sagirani, T. (2014). Inculcation Method of Character Education Based on Personality Types Classification in Realizing Indonesia Golden Generation. International Journal of Evaluation and Research in Education (IJERE), 3(2), 91-98. https://doi.org/10.11591/ijere.v3i2.4199.

Supraptiningrum, \& Agustini. (2015). Membangun Karakter Siswa melalui Budaya Sekolah di Sekolah Dasar. Jurnal Pendidikan Karakter, 2, 219-228. https://doi.org/10.21831/jpk.v0i2.8625.

Utami, I. G. A. L. P. (2012). Character Education Through Peer Assessment. Jurnal Pendidikan Karakter, 3, 1-16. https://doi.org/10.21831/jpk.v0i3.1293. 
Yanti, N., Adawiah, R., \& Matnuh, H. (2016). Pelaksanaan Kegiatan Ekstrakurikuler dalam Rangka Pengembangan Nilai-nilai Karakter Siswa untuk Menjadi Warga Negara yang Baik di SMA Korpri Banjarmasin. Jurnal Pendidikan Kewarganegaraan, 6(11), 963-970. http://dx.doi.org/10.20527/kewarganegaraan.v6i11.746.

Zubaedi. (2012). Desain Pendidikan Karakter: Konsepsi dan Aplikasinya dalam Lembaga Pendidikan (II). Jakarta: Kencana Prenada Media Group. 